Marcin ŻÓŁKOŚ

Michał GDULA ${ }^{2}$

\title{
WPLYW WPROWADZENIA DRGAŃ ULTRADŹWIĘKOWYCH DO PROCESU SZLIFOWANIA STOPU INCONEL 718
}

\begin{abstract}
W artykule przedstawiono badania eksperymentalne procesu szlifowania wspomaganego ultradźwiękami (UAG). Celem pracy było ustalenie wpływu wprowadzenia drgań ultradźwiękowych przedmiotu obrabianego do procesu szlifowania konwencjonalnego stopu Inconel 718 na składowe siły szlifowania i chropowatość powierzchni. Badania przeprowadzono według programu statycznego randomizowanego kompletnego, rejestrując wartości składowej normalnej i stycznej siły szlifowania oraz parametru $R a$ chropowatości powierzchni. Pomiary wykonano zarówno dla procesu wspomaganego, jak i konwencjonalnego. Zmierzone wartości wielkości wyjściowych zaprezentowano na wykresach. Na ich podstawie można zaobserwować, że wprowadzenie drgań ultradźwiękowych do procesu szlifowania spowodowało zmniejszenie wartości składowych siły szlifowania w przyjętych zakresach parametrów nastawnych. Określono również oddziaływanie wspomagania drganiami ultradźwiękowymi na parametr chropowatości $R a$.
\end{abstract}

Słowa kluczowe: procesy hybrydowe, szlifowanie wspomagane ultradźwiękami, składowe siły szlifowania, chropowatość powierzchni

\section{Wprowadzenie}

Dynamiczny rozwój różnych gałęzi przemysłu, w tym głównie lotniczego, motoryzacyjnego, chemicznego i medycznego, obliguje do stosowania specjalnych materiałów, takich jak stopy na bazie niklu (np. Inconel 718). Stopy te, ze względu na swoje właściwości, przysparzają wielu problemów w obróbce ubytkowej [3-5]. Ponadto z uwagi na ciągłe podnoszenie efektywności wytwarzania współczesnych części maszyn z tych materiałów istnieje potrzeba prowadzenia prac badawczo-rozwojowych, związanych $\mathrm{m}$.in z nowoczesnymi procesami szlifowania. Szczególnie dotyczy to procesów hybrydowych, do których należy proces szlifowania ze wspomaganiem ultradźwiękowym UAG (Ultrasonic Assisted Grinding) [3, 4].

\footnotetext{
${ }^{1}$ Autor do korespondencji/corresponding author: Marcin Żółkoś, Politechnika Rzeszowska, ul. W. Pola 2, 35-959 Rzeszów, tel.: 178651411, e-mail: markos@ prz.edu.pl

${ }^{2}$ Michał Gdula, Politechnika Rzeszowska, e-mail: gdulam@prz.edu.pl
} 
Inconel 718, jak i pozostałe stopy na bazie niklu, charakteryzuje wysoka wytrzymałość w podwyższonych temperaturach, odporność na korozję i utlenianie oraz duża wytrzymałość zmęczeniowa. Stopy te posiadają jednak niską przewodność cieplną, co w przypadku obróbki ubytkowej jest wadą, gdyż dochodzi do akumulacji dużych ilości ciepła w strefie styku ściernicy z przedmiotem obrabianym. Wpływa to na szybsze zużywanie się ściernicy oraz pogorszenie dokładności obrabianego przedmiotu [7].

$\mathrm{Z}$ powodu wspomnianych właściwości Inconelu 718, w trakcie jego obróbki powstają duże wartości składowych siły szlifowania, co negatywnie wpływa m.in na utrzymanie tolerancji wymiarowo-kształtowej wytwarzanych części [5]. W tym aspekcie szlifowanie ze wspomaganiem ultradźwiękowym może stanowić alternatywę dla konwencjonalnych technologii obróbki, pozwalając na znaczną poprawę dokładności szlifowanych przedmiotów $[5,6]$.

W pracy [1] wykazano, że proces szlifowania z posuwem pełzającym stopu Inconel 718 wspomagany drganiami ultradźwiękowymi ściernicy korundowej pozwala na zmniejszenie składowych siły szlifowania. Zaobserwowano także mniejsze zużycie ściernicy i poprawę współczynnika $G$, określającego stosunek zeszlifowanego materiału przedmiotu do ubytku ściernicy. Autorzy tej publikacji wykazali także, że zastosowanie wspomagania ultradźwiękowego prowadzi do wzrostu liczby krawędzi skrawających ściernicy biorących udział w skrawaniu, co powoduje obniżenie średniej wartości parametru $\mathrm{Sa}$. Taki stan rzeczy determinuje konieczność prowadzenia dalszych badań procesu szlifowania ze wspomaganiem ultradźwiękowym i jego udoskonalanie, np. przez wprowadzenie drgań ultradźwiękowych obrabianego przedmiotu [3]. Celem niniejszej pracy jest zatem określenie wpływu wprowadzenia drgań ultradźwiękowych przedmiotu obrabianego do procesu szlifowania stopu Inconel 718 na składowe siły szlifowania i chropowatość powierzchni.

\section{Warunki badań doświadczalnych}

Badania eksperymentalne przeprowadzono na stanowisku badawczym, zbudowanym na potrzeby realizacji projektu PBS2/B6/17/2013 [2]. Podstawę tego stanowiska stanowi centrum obróbkowe HAAS VF-2YT z układem sterującym Sinumerik 840D sl, umożliwiającym sterowanie parametrami generatora ultradźwiękowego z poziomu programu technologicznego. Do pomiarów składowych siły $\mathrm{w}$ procesie szlifowania wspomaganego drganiami ultradźwiękowymi zastosowano siłomierz z czterema czujnikami piezoelektrycznymi typu 9601A3110000 firmy Kistler. Pomiary chropowatości zostały wykonane za pomoca profilometru MarSurf PS 10 firmy Mahr. Dodatkowo stanowisko wyposażono w falowód, czyli układ wzbudzający drgania ultradźwiękowe o częstotliwościach rzędu około $20 \mathrm{kHz}$. W skład tego układu wchodził generator wysokonapięciowego prądu przemiennego, wzbudnik drgań ultradźwiękowych (transducer) o nominalnej częstotliwości rezonansowej $20 \mathrm{kHz}$, wzmacniacz 
drgań (booster) o współczynniku wzmocnienia amplitudy drgań 1:1,5 oraz element wykonawczy (sonotroda) z zamocowanym przedmiotem obrabianym.

Materiałem obrabianym był stop Inconel 718. Do przeprowadzenia badań zastosowano narzędzie w postaci czołowej tarczy szlifującej firmy Urdiamant 6A2 100-6/4 D151 K100 H20 B-IIIBK o nasypie diamentowym, wielkości ziaren 151 oraz spoiwie żywicznym. Jako czynnik chłodząco-smarujący zastosowano $5 \%$ emulsję syntetyczną podawaną zalewowo do strefy szlifowania.

Badania eksperymentalne przeprowadzono w układzie szlifowania czołowego ze ściernicą realizującą ruch posuwowy w kierunku prostopadłym do osi fali mechanicznej wymuszającej drgania ultradźwiękowe. W ramach projektu badawczego [2] opracowano specjalną geometrię przedmiotu obrabianego oraz sonotrodę o częstotliwości rezonansowej $21,093 \mathrm{kHz}$, przystosowaną do współpracy z przedmiotem obrabianym, jak również mocowanie mechaniczne próbki badawczej do powierzchni czołowej elementu wykonawczego falowodu. Kształt przedmiotu obrabianego umożliwiał szlifowanie płaskiej powierzchni o szerokości $3 \mathrm{~mm}$ i długości $20 \mathrm{~mm}$, co zapewniło utrzymanie stałej wartości przekroju usuwanej warstwy materiału.

Stałe warunki badań zapewniono, przeprowadzając proces kondycjonowania ściernicy ze stałymi parametrami (wartości średnie z wymienionych dalej przedziałów zmienności) przed każdym programem badawczym, aby początkowy proces jej docierania nie zakłócał wyników pomiarów. Przed każdym przejściem pomiarowym wykonywane było jedno przejście wyrównujące próbkę bez wspomagania ultradźwiękowego wraz z pięcioma przejściami wyiskrzającymi. Po każdym przejściu pomiarowym przeprowadzano osiem przejść wyiskrzających.

Jako czynniki wejściowe, mające wpływ na składową styczną i normalną siły szlifowania oraz chropowatość powierzchni, założono następujące parametry technologiczne procesu o podanych przedziałach zmienności:

- prędkość obwodowa $v_{s}=10-20 \mathrm{~m} / \mathrm{s}$,

- posuw $v_{f}=1000-3000 \mathrm{~mm} / \mathrm{min}$,

- głębokość szlifowania $a_{e}=0,02-0,05 \mathrm{~mm}$ (maksymalna wartość zależna od średniego rozmiaru ziarna ściernego).

Aby zbadać wpływ drgań ultradźwiękowych na siłę szlifowania chropowatości powierzchni przy zmieniających się wartościach poszczególnych parametrów nastawnych, posłużono się programem statycznym randomizowanym kompletnym, w którym wielkościami wejściowymi były wymienione wcześniej parametry technologiczne. Przyjmowały one wartości na trzech poziomach zmienności. Program ten wymagał wykonania w losowej kolejności pomiarów (powtarzanych pięciokrotnie) dla trzech układów, w których jeden parametr zmieniał swoją wartość, natomiast pozostałe przyjmowały wartość z połowy zakresu zmienności. W celach porównawczych wszystkie pomiary zostały wykonane bez wspomagania procesu ultradźwiękami, jak i ze wspomaganiem, gdzie wartość amplitudy drgań zmierzona za pomocą bezstykowego systemu pomiarowego przemieszczeń eddyNCDT 3300 wynosiła $6 \mu \mathrm{m}$. Wielkościami mierzonymi 
w tym procesie była siła szlifowania, a dokładniej jej składowe - normalna $\left(F_{n}\right)$ i styczna $\left(F_{t}\right)$ oraz parametr $R a$ chropowatości powierzchni mierzony w kierunku prostopadłym i równoległym do posuwu.

\section{Wyniki badań doświadczalnych}

Badania doświadczalne realizowano, zestawiając proces szlifowania ze wspomaganiem drganiami ultradźwiękowymi przedmiotu obrabianego z procesem szlifowania konwencjonalnego w tych samych warunkach. Na rysunkach 1-3 porównano uzyskane doświadczalnie wartości składowych siły szlifowania dla obydwu procesów - szlifowania wspomaganego ultradźwiękami (z UAG) i szlifowania konwencjonalnego (bez UAG).

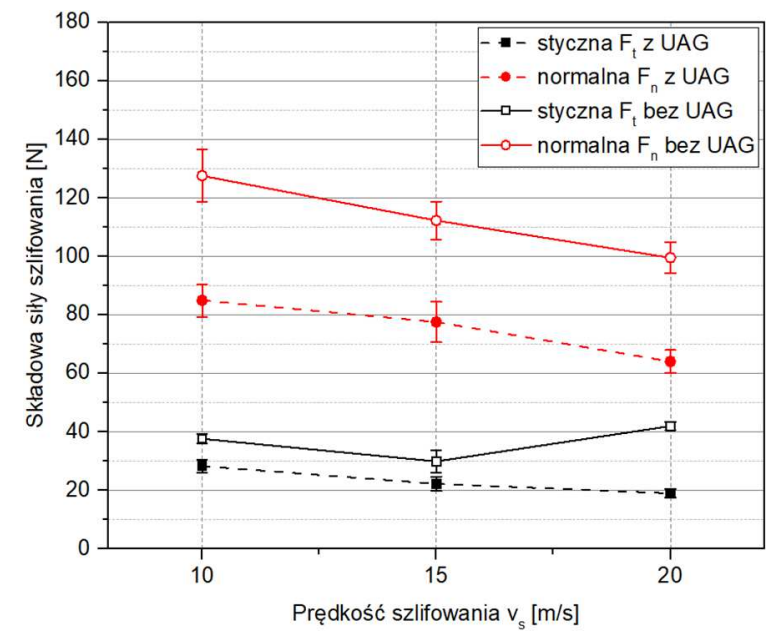

Rys. 1. Wpływ prędkości szlifowania na składowe siły szlifowania

Fig. 1. Effect of grinding speed on grinding force components

Na podstawie wyników badań można zaobserwować (w przyjętym zakresie parametrów nastawnych) korzystny wpływ wprowadzenia drgań ultradźwiękowych do procesu szlifowania stopu Inconel 718, polegający na zmniejszeniu wartości składowych siły szlifowania zarówno normalnej, jak i stycznej. Uzyskane tendencje zmian składowych siły szlifowania są zgodne z prezentowanymi w literaturze. Na rysunku 1 można zaobserwować spadek wartości składowych wraz ze zwiększaniem prędkości szlifowania. Wraz ze wzrostem wartości posuwu i głębokości szlifowania obserwuje się wzrost składowych siły szlifowania (rys. 2 i 3). Tendencje te są zachowane zarówno dla procesu konwencjonalnego, jak i wspomaganego drganiami ultradźwiękowymi.

Jednocześnie wartości składowych siły szlifowania uzyskiwane w procesie wspomaganym drganiami ultradźwiękowymi były istotnie mniejsze (dla przyjętego zakresu parametrów nastawnych) niż w przypadku procesu konwencjonalnego. Można również zauważyć, że zarówno w przypadku składowej normalnej, 
jak i stycznej największą redukcję wartości poszczególnych składowych obserwuje się dla największej głębokości szlifowania (rys. 3).

Rys. 2. Wpływ posuwu szlifowania na składowe siły szlifowania

Fig. 2. Effect of grinding feed on grinding force components

Rys. 3. Wpływ głębokości szlifowania na składowe siły szlifowania

Fig. 3. Effect of grinding depth on grinding force components
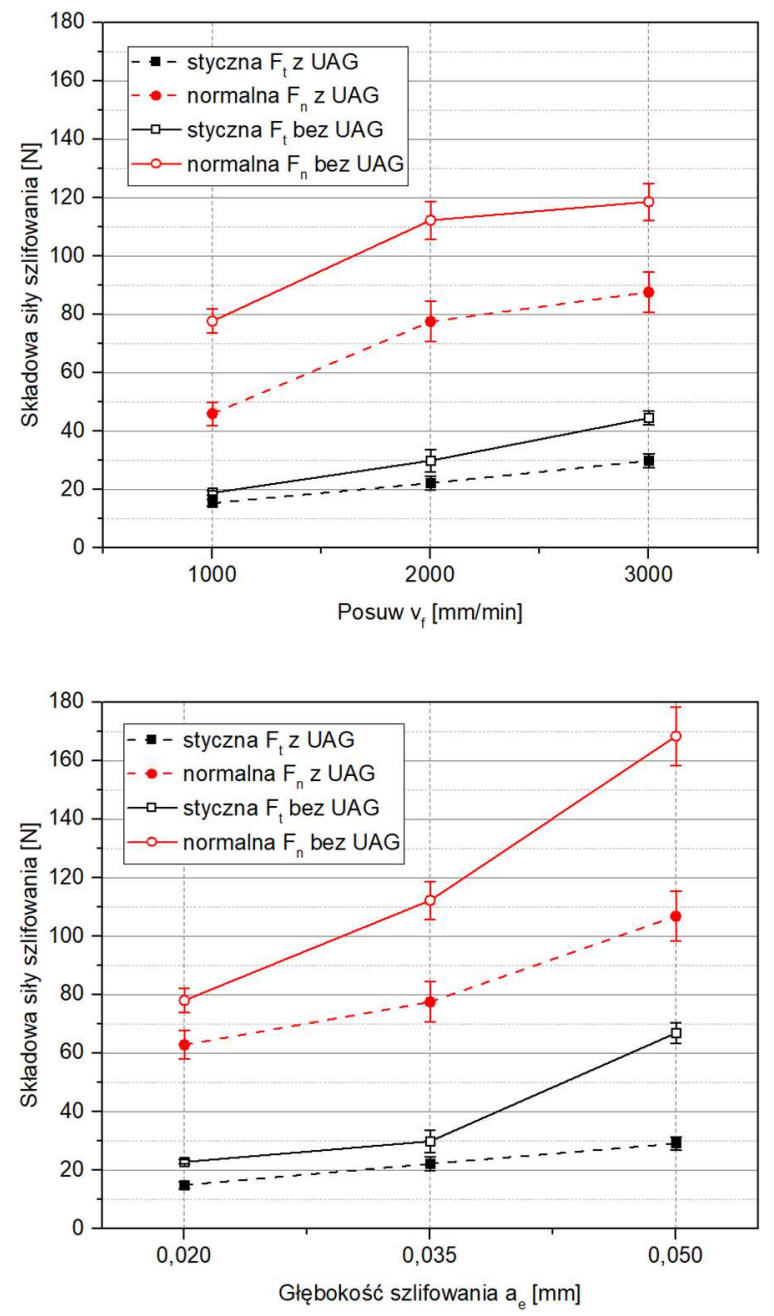

Na rysunku 4 zaprezentowano wyniki pomiarów wartości parametru chropowatości $R a$ po procesie wspomaganym drganiami ultradźwiękowymi i po procesie konwencjonalnym. Pomiary przeprowadzono w kierunku równoległym i prostopadłym do kierunku posuwu. Wartości na wykresach stanowią średnią z 5 pomiarów z wyznaczonym przedziałem ufności dla poziomu istotności równego 0,05 .

W przypadku pomiarów wartości parametru chropowatości $R a$ nie uzyskano wyników pozwalających na jednoznaczną ocenę. Można jednak zaobserwować, że dla szlifowania konwencjonalnego chropowatość mierzona prostopadle do 
a)

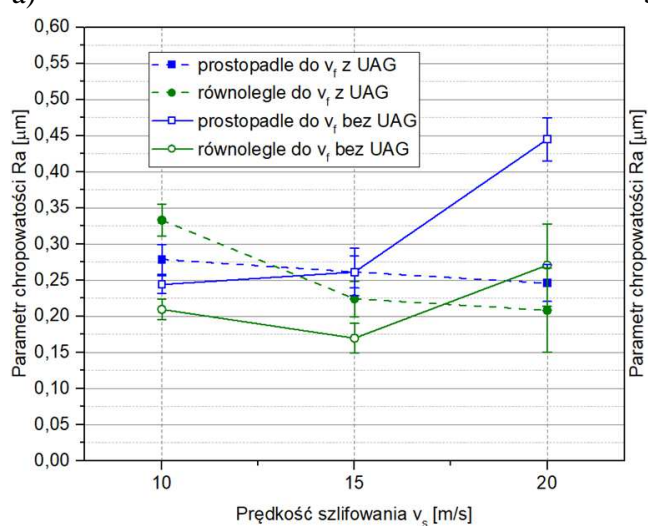

b)

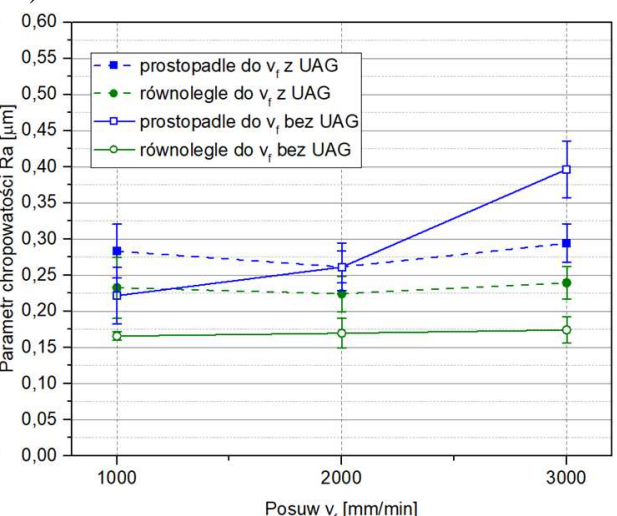

c)

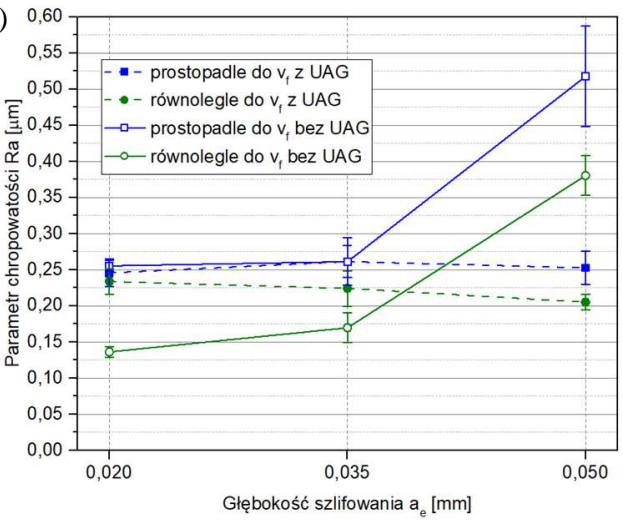

Rys. 4. Wpływ: a) prędkości szlifowania, b) posuwu szlifowania, c) głębokości szlifowania na chropowatość powierzchni

Fig. 4. Effect of: a) grinding speed, b) grinding feed, c) grinding depth on surface roughness

kierunku posuwu jest zdecydowanie większa niż mierzona równolegle do posuwu, podczas gdy dla szlifowania wspomaganego ultradźwiękami różnica ta jest znacznie mniejsza. Jest to spowodowane zwiększeniem chropowatości mierzonej w kierunku równoległym do posuwu w wyniku dodatkowego ruchu względnego narzędzia i przedmiotu obrabianego pochodzącego od wprowadzonych drgań. Można zatem stwierdzić, że wprowadzenie drgań ultradźwiękowych powoduje większą izotropowość struktury geometrycznej powierzchni. Największe różnice w wartości parametru $R a$ pomiędzy procesem konwencjonalnym i wspomaganym obserwuje się dla najwyższych wartości głębokości szlifowania. Zastosowanie w tym przypadku drgań ultradźwiękowych nie tylko spowodowało zmniejszenie chropowatości, ale również zniwelowało wpływ głębokości szlifowania na parametr chropowatości $R a$. 


\section{Podsumowanie}

Przeprowadzone badania wykazały korzystny wpływ wspomagania, drganiami ultradźwiękowymi przedmiotu obrabianego, procesu szlifowania stopu Inconel 718 zarówno na składową normalną oraz styczną, jak i chropowatość powierzchni. Zastosowanie wspomagania procesu ultradźwiękami pozwoliło na zmniejszenie, w całym badanym zakresie, siły normalnej $F_{n}$ od 19 do $57 \%$ oraz siły stycznej $F_{t}$ od 19 do $41 \%$ względem szlifowania konwencjonalnego w takich samych warunkach. W przypadku chropowatości powierzchni zaobserwowano korzystny wpływ drgań ultradźwiękowych, polegający na zwiększeniu izotropowości struktury geometrycznej powierzchni. Zaobserwowano również stabilizację wartości parametru chropowatości powierzchni $R a$ w całym badanym zakresie w przypadku szlifowania ze wspomaganiem ultradźwiękowym. Pozwala to na zwiększenie wydajności szlifowania przy zachowaniu takiej samej chropowatości. Należy jednak zaznaczyć, że potwierdzenie tych tendencji będzie wymagać dalszych, rozszerzonych badań.

\section{Literatura}

[1] Bharudi D., Soo S.L., Aspinwall D.K., Novovic D., Haden P., Bohr S., Martin D.: A study on ultrasonic assisted creep feed grinding of nickel based superalloys, 5-th CIRP Conf. High Performance Cutting (2012), pp. 359-364.

[2] http://www.ktwia.prz.edu.pl/projekt-badawczy-pbs2b6172013 (dostęp: 12.06.2017 r.).

[3] Krok M., Porzycki J., Żółkoś M.: Wybrane zagadnienia projektowania sonotrod na potrzeby obróbki ubytkowej wspomaganej drganiami ultradźwiękowymi obrabianego przedmiotu, Mechanik, 89 (2016) 1354-1355.

[4] Ming C., Xiaotian L., Fanghong S., Yucheng X., Bingyuan X.: Studies on the grinding characteristics of directionally solidifed nickel-based superalloy, J. Mat. Proc. Technol., 16 (2001) 165-169.

[5] Ostrowski D., Sikora M., Kruszyński B.: Wpływ warunków obróbki stopu Nickel 201 na efekty procesu szlifowania, Mechanik, 88 (2015) 42-46.

[6] Porzycki J., Habrat W., Wdowik R.: Możliwości zastosowania szlifowania ze wspomaganiem ultradźwiękowym w przemyśle lotniczym, Mechanik, 86 (2013) 2CD, s. $1-9$.

[7] Tso P.: Study on the grinding of Inconel 718, J. Mat. Proc. Technol., 55 (1995) 421-426.

\section{EFFECT OF INTRODUCING THE ULTRASONIC OSCILLATIONS TO GRINDING PROCESS OF INCONEL 718 ALLOY}

\section{S u m m a r y}

This paper presents experimental research of ultrasonic assisted grinding (UAG) process. The aim of this study was to determine the influence of introducing workpiece ultrasonic oscillations to conventional grinding process of Inconel 718 alloy on grinding force components and surface 
roughness. The investigations were conducted based on completely randomized design acquiring the values of normal and tangential grinding force components and surface roughness $R a$ parameter. Measurements were performed for ultrasonic assisted process as well as conventional process. Obtained values of output parameters were presented on graphs. It was observed that, the introduction of the ultrasonic vibrations to the grinding process results in a reduction of grinding force components (for adopted range of process parameters). The effect of ultrasonic oscillations in grinding process on surface roughness parameter $R a$ was also evaluated.

Keywords: hybrid processes, ultrasonic assisted grinding, grinding force components, surface roughness

DOI: $10.7862 / \mathrm{rm} .2017 .35$

Otrzymano/received:12.07.2017

Zaakceptowano/accepted: 22.09.2017 